\title{
Now What Do I Do With Brad And Kerry?
}

Anthony J. Mento, Loyola University in Maryland, USA

Jay E. Cougnet, Loyola University in Maryland, USA

Christy L. De Vader, Loyola University in Maryland, USA

\begin{abstract}
As the Great Recession continued, Jason, a project manager for the past six years with a large general contracting firm, NewBuild, pondered the burden of being an effective leader and manager in such trying times. He had to make a choice of which of his two most recently hired engineers, Brad or Kerry, would be assigned to the next big construction project. Both were direct reports to Jason for the past nine months. Unfortunately, there was a strong possibility that if the economy continued downward, the one not chosen to be on the new project team could be terminated due to lack of work.
\end{abstract}

Jason, a project manager at NewBuild a large general contracting firm was faced with a staffing dilemma that confronts many managers in tough economic times. He had to decide whom to promote among his two most recently hired engineers to the next big construction project. Unfortunately, there was a strong possibility that the one not chosen to be on the new project team would be terminated due to lack of work.

His charge was to take a comprehensive view of the situation and make a decision that was best for Brad, Kerry and NewBuild. As is always the case, a manager has a finite amount of information from which a decision must be made. Complicating matters was the gloomy economy for NewBuild as well as the prospect of providing a challenging job in a no growth environment.

This note focuses on issues such as the psychological contract between NewBuild and the new employees as providing a context that serves either to fully engage new employees or which provides a milieu which only ensures physical presence on the job. Jason also needed to consider the extent to which Brad and Kerry engaged in the important skill of upward management. He wanted to stretch his understanding of Level 3 leadership (Clawson, 2009) by carefully sifting through what he knew about Brad and Kerry in order to identify important values, assumptions, beliefs, and expectations, (VABEs) arising at the unconscious level that nevertheless direct employee behavior. Finally, he needed to assess the significance of written email communication of lessons learned through Tannen's (1995) lens for understanding stylistic communication differences. Performance appraisal data was also available as were observations of both engineers on a negotiation simulation. Jason had to synthesize this information to form a clear picture in his mind about whom to promote to the project team and who by default is left in limbo perhaps awaiting the pink slip to downsize.

This decision critical incident which is based on a true incident in a disguised organization, may be used in the following courses: Management, Leadership, Career Development, Organizational Behavior, and Human Resources Management.

Keywords: Psychological Contract; Values; Assumptions; Beliefs; Expectations; VABES; Managing Upward; Linguistic Style Differences; Promotion

\footnotetext{
${ }^{1}$ Disclaimer: This case was prepared by Anthony J. Mento, Jay E. Cougnet and Christy L. De Vader of Loyola University Maryland and is intended to be used as a basis for class discussion. These views represented here are those of the case authors and do not necessarily reflect the views of Loyola University Maryland. Authors' views are based on their own professional judgments. The names of the organization, individuals and location have been disguised to preserve the organization's request for anonymity.
} 


\section{INTRODUCTION}

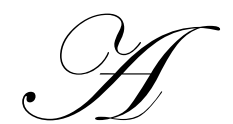

$\mathrm{s}$ the Great Recession continued, Jason, a project manager for the past six years with a large general contracting firm, NewBuild, pondered the burden of being an effective leader and manager in such trying times. He had to make a choice of which of his two most recently hired engineers, Brad or Kerry, would be assigned to the next big construction project. Both were direct reports to Jason for the past nine months. Unfortunately, there was a strong possibility that if the economy continued downward, the one not chosen to be on the new project team could be terminated due to lack of work.

Jason had a plethora of information about the two on which to make the decision, but he had not yet assembled all of the disparate pieces of information into a coherent picture.

In order for him to take a more systemic approach to this staffing decision, he wanted to revisit the psychological contract established between NewBuild and Brad and Kerry. He wondered also which one of the two employees had done the better job of managing him. More broadly he wanted to understand the values, assumptions, beliefs, and expectations (VABEs) that people bring to work; i.e., why people behave the way that they do. In addition to carefully taking into account their last performance appraisal, he wanted to make sure that he was judging fairly any linguistic style differences observed in a completed lessons learned assignment received from Kerry and Brad.

\section{Brad And Kerry- What Jason Already Knows}

Brad and Kerry joined NewBuild in January of 2009. Both Brad and Kerry were technically proficient with construction-related topics; Brad's degree was in construction engineering, while Kerry's was in architectural engineering. Kerry had additional experience as an undergraduate working closely with a professor who conducted research on new design techniques for the construction industry, including building information modeling and virtual design. Brad and Kerry were assigned to Jason since their arrival on the job. Unfortunately, due to the economic downturn, Brad and Kerry had not yet been assigned to a significant project.

Jason had a difficult time getting to know Brad, who seemed reticent to speak and was introverted. Typically, Jason actively questioned Brad for any updates regarding his responsibilities. In general, Brad simply answered Jason's questions and provided little detail without follow up questions from Jason. He seemed to have no idea what Jason's goals and objectives were or how to best provide Jason with this needed information. This frustrated Jason at times because he did not always have enough time to track down Brad for more detailed answers. He would have preferred Brad to take the initiative to seek him out. Jason thought over the past months that he needed to make his expectations of Brad as his direct report clearer before assigning him to a full-time project. Even so, Jason still had concerns whether Brad's introverted personality and seemingly passive behavior would prevent him from doing a better and more active job providing Jason with important information when he needed it, and in the form that he needed it.

Fortunately for Jason, by chance, Brad's cubicle wall was adjacent to his and additional information about Brad as an employee had been gleaned. Jason had overheard many phone conversations between Brad and others. Brad seemed to be very succinct and demanding of those to whom he spoke, especially if they were not in a position of authority over him. Given all of this, Jason was perplexed with respect to understanding how Brad would react to adversity on a project site.

Kerry was extremely outgoing in the office and tactfully expressed her opinions when the occasion arose. She regularly provided Jason with updates on her unfinished tasks and gave elaborate details of her important conversations with others on whom she was dependent. Because of Kerry's approach to managing Jason, he rarely felt the need to ask her more questions. Other interactions with Kerry had been useful to understanding her a little better as a person. She had an extremely regimented diet and rarely went out with other group members for lunch. She had not been able to participate in group activities due to other commitments with her boyfriend or family. However, she pursued an active interest in what group members were doing. She often mentioned that she did not have many friends outside of work except for her boyfriend, Gary. 
Jason conducted a training session recently that involved a negotiation simulation with all of his employees. Jason placed Brad in a group that included two very strong personalities that were placed in competing positions. Jason deliberately assigned Brad to a role that provided an opportunity for Brad to be a leader in developing alliances with the other parties in the simulation. Jason figured this would have forced Brad into a position that allowed him to demonstrate his leadership in coming to a resolution. However, during the simulation, Brad aligned himself with the other participants in the simulation in such a way that allowed them to argue the issue for him. He never took the lead in negotiating for his own position. This strategy worked well for the negotiation simulation, but Jason was concerned that Brad had demonstrated excessive passivity. Jason wondered how Brad would lead a troubled contractor toward completing a project when placed in such a position.

During the same negotiation simulation, Kerry was matched up with a tough opponent as well, although Jason did not realize that was going to be the case. Kerry admitted that she read the simulation material a few days before the actual simulation exercise took place so that she came to the situation rather ill prepared. This left Kerry extremely vulnerable during the negotiation exercise and she was taken to task during the simulation. Jason wondered if Kerry's disappointing performance would be indicative of her reaction to actual on-the-job adversity. When Jason took into account her lack of preparation, he was impressed with Kerry's ability to "think on her feet" and debate points well enough to survive but not well enough to develop a clearly commanding position in the negotiation exercise.

On more than one occasion, Jason had heard Brad and Kerry discussing one of Jason's most valuable employees, Dixon. Brad and Kerry could not help but notice that Dixon was Jason's "right hand man." Dixon and Jason both seemed to work in synchronicity of which this harmonious relationship was generally attributed by most people at NewBuild as just a case of "good chemistry". It did not occur to them that the deliberate ease of manner in which Dixon seemed to work with Jason was by design. Brad and Kerry did not realize managing upward was a valuable skill that Dixon had mastered and that could be practiced and readily learned.

Jason was required to conduct performance reviews on each of his employees. A simple review form was provided and required rating each employee on the following set of characteristics: commitment to company goals, quality of work, attitude, treatment of others, communication, work management, time management, dependability, cooperation, and job knowledge. Jason believed his employees deserved a more comprehensive performance review than was encompassed using this form alone, so he usually spent an hour or more with each employee to go over their individual goals. Both Brad and Kerry had identical scores on all the dimensions rated. All scores were in the middle of the 5 point range - with 3 being "meets expectations."

\section{Jason: The Project Manager}

Jason joined NewBuild in 1997 as an intern after his second year of college. Jason became a full time employee in 1999 upon graduation from his civil engineering program. His internship experience provided him with knowledge of the company and its culture which proved to be a significant advantage over other project engineers that were hired at the same time. Within two years, Jason was promoted to assistant project manager and then to project manager two years later. Even prior to his promotions, Jason had been managing other engineers and interns since his first year as a full time employee.

Jason wondered exactly what had attracted him to NewBuild when he was a recent graduate and why he stayed and seemed to thoroughly enjoy his work. He felt that he was treated fairly and that the exchange between what he brought to the table and what he received in return seemed equitable. The voluntary turnover rate at NewBuild was higher than the company desired as a result of lower salaries than the industry average, therefore he assumed that employees who chose to stay at NewBuild were satisfied with the higher degrees of responsibility young engineers were provided. He thought that it would be a valuable exercise to explore the psychological contract (the unwritten agreement pertaining to outputs provided to the organization in return for inputs from the firm) between NewBuild and Brad and Kerry. Jason wanted to determine if changes needed to be made in the recruiting brochure, NewBuild's image, etc. He wanted to discover to what degree, if any, the changing nature of the psychological contract between NewBuild and Brad and Kerry had shaped their performance. A psychological contract can serve to fully engage employees actively in the work going on in the organization or it can create 
conditions so that employees are psychologically limited to being only physically present on the job. Brad wondered if NewBuild's present psychological contract was an enabler or a roadblock to high performance.

Jason had nearly completed his MBA at a nationally ranked part-time program. He was especially attentive in courses dealing with issues of leadership, management, and power and influence. This explicit focus solidified his ability to understand why employees do the things that they do. Jason had come a long way in better understanding his employees' values and beliefs. Feedback from his employees led him to believe that he was widely perceived to be approachable with questions, sympathetic to employee needs, a good developer of talent and an effective mentor.

In his quest to continuously improve as a manager and leader at NewBuild, Jason had become intrigued with an approach to leadership that he came across in his MBA studies. Level 3 leadership (Clawson, 2003) posits that in order to have a major impact on an employee, the manager needs to impact this employee at 3 levels: level 1 - the behavioral level, level 2 - the conscious thinking level, and level 3 - the unconscious level in which important values, assumptions, beliefs, and expectations (VABEs) can be found. Jason knew that most managers could impact actions and thinking, but it was the rare manager who could identify and act upon an employee's VABEs. Uncovering an employee's VABEs was a deliberate process of questioning, listening, and discovery. Jason believed that by knowing the VABEs of Brad and Kerry he would be in a better position to guide and coach them on their career path with NewBuild. Jason hoped this would result in Brad and Kerry becoming more productive and satisfied employees.

As Jason continued to advance within the company's ranks, his responsibilities as developer and manager broadened to also include sales management. The company expected their upper level managers to spend an increasing amount of time securing work for their employees. At Jason's level, he was expected to spend at least $25 \%$ of his time soliciting business for NewBuild. So, if he was successful finding new business, he would then be in a better position to assign employees like Brad and Kerry to challenging projects affording significant developmental opportunities for learning and growth. The increased sales management component of his job directly impacted the time Jason had to develop and nurture his newest employees in the ways he had done in the past. As a result, he needed employees that tended to be self-starters and who were capable of actively managing the relationship with him as they would any other aspect of a project in order to produce mutually beneficial results.

\section{The Company}

NewBuild was founded in 1909 and enjoyed conservative and steady growth since its establishment. The company had no long-term debt and held substantial cash reserves with which to withstand a long term economic decline. The previous five years were characterized by unprecedented growth. Based on this, employees of the company had an expectation that they would be regularly assigned onsite to ongoing construction projects with little need to spend time in the main office.

NewBuild's mission statement focused on high integrity, customer delight, and dedication to each employee's personal career growth. The mission of NewBuild is to build on our reputation for integrity, excellence, experience and leadership as the nation's finest construction organization by:

- $\quad$ Continuously improving the quality of our work and services.

- Constantly striving to exceed each client's expectations.

- Maintaining our dedication to the highest moral principles.

- $\quad$ Providing our people with a challenging, secure and safe environment in which to achieve personal career goals.

A severe recession began in 2008 and was impacting the commercial construction industry dramatically. Although, the company expected to have 2009 revenues similar to those between 2005 and 2008, it expected lower revenues between 2010 and 2012. NewBuild planned to spend a significant portion of their cash reserves in order to prevent layoffs through 2010. Further, if the economy did not quickly turn around, the company would struggle to break even due to its high overhead expenses. 
Every college recruit for NewBuild had seen the company's motto, "If you are looking for a job, look elsewhere. If you are looking for a career, choose us!" NewBuild's policy to promote from within had established an experienced cadre of employees that were dedicated to career development. Every employee understood that their career advancement was predicated on their subordinate's advancement. Therefore, all managers attempted to provide for their employees strategically chosen career development opportunities that offer them maximum exposure to other managers within NewBuild and potential new clients outside of the company.

Construction was still a male dominated industry. NewBuild's employee roster reflected this fact despite its efforts to improve the situation. The first promotion of a woman to a vice president position in NewBuild's history occurred in 2006 and out of 90 operating groups, just three were managed by women. Within his division, Jason had more female employees than any other project manager. Out of the seven project managers and engineers he supervised, four were women. He tried to provide all with the best opportunities possible to succeed and to enjoy their experience within the company.

\section{The Client}

Part of Jason's job was to evaluate the client's expectations of the project team. Based on his past experience working with this particular client, he noted that they were extremely demanding and expected peak performance from everyone. Coupled with Jason's increased role of finding new work, he knew there would be little time for coaching his new employees. It was typical for the client to discuss project matters with all team members rather than going through their point person, which was Jason. Jason's fear was that Brad would not have been forthcoming in his analysis of critical matters which would have required the client to ask a lot of questions to get their answers. Additionally, Jason feared Brad would not proactively communicate with the owner on critical issues. He believed Brad would take the position of waiting to be asked rather than anticipating the concerns and addressing them. However, Brad's technical expertise would have provided the necessary anchor for the complex nature of the project. Kerry's outgoing demeanor would have served her well with the client; however, her lower degree of technical expertise may have her "in over her head." Jason would have needed to provide a support system in the team to prop up her technical shortcomings. Fortunately, Dixon, Jason's trusted employee was scheduled to play this role on the next big project for any newcomers who needed such support. Jason did not believe that for this particular client, gender would be a problem since Jason's project team was well balanced with men and women in important and equally responsible positions.

The most immediate task facing Jason was to decide whether to promote Brad or Kerry to the lone position available on the imminent next big construction project. He wanted to thoroughly review the psychological contract between NewBuild and Brad and Kerry to determine if it served as an enabler or inhibitor to high performance. Also under review, along with their performance appraisal, was an assessment of the skill manifested by Brad and Kerry in actively managing him. In addition, Jason knew that he wanted to develop a set of VABEs for Brad and Kerry and that a thorough analysis of stylistic differences presented in a lessons learned email (See Appendix) might have added to the information needed to make a decision. Also available for scrutiny were Jason's perceptions of the performance of his two newest employees on a simulated negotiation exercise. Over time, Jason had collected quite a bit of information about Brad and Kerry. He had not yet connected all of the pieces of the puzzle. Now he needed to make sense of this data to help him decide whom to promote to the open position on the next big project.

\section{AUTHOR INFORMATION}

Anthony J. Mento, Ph.D. is a Professor of Management in the Department of Management and International Business in the Sellinger School of Business and Management at Loyola University Maryland. His research interests are in creativity, change management, case writing, and reflection as a technique for managerial learning. Some of his publications are in the Journal of Applied Psychology, The Journal of Management, Organizational Behavior and Human Decision Processes, The Journal of Change Management, the Journal of Management Development, the Journal of Critical Incidents, and the Journal of Executive Education. E-mail: Amento@loyola.edu. Corresponding author. 
Jay Cougnet is a senior project manager at one of the oldest and largest building contracting companies in the United States. Cougnet's career in project management started in 1997. He has been involved with over forty projects totaling over $\$ 215$ million. Cougnet obtained a Bachelor of Science in Civil Engineering from University of Maryland, College Park and has a Master of Business Administration from Loyola University. Cougnet has been an affiliate faculty member at Loyola University since September 2010. E-mail: jcougnet@ loyola.edu.

Christy L. De Vader, Ph. D. is an Associate Professor of Management and International Business in the Sellinger

School of Business and Management at Loyola University Maryland. Her areas of expertise include career management, team development, and cross-cultural talent management. E-mail: cdevader@loyola.edu.

\section{REFERENCES}

1. Beer, M. (2009). High commitment high performance: How to build a resilient organization for sustained advantage. San Francisco, CA: Jossey-Bass.

2. Clawson, J. G. (2001). Note: A leader's guide to why people behave the way they do. UVA-OB-0744, Darden Business Publishing.

3. Clawson, J. G. (2009). Level three leadership: Getting below the surface. 4th edition. Upper Saddle River, NJ: Pearson/Prentice Hall.

4. Collins, J. (2001). Good to great: Why some companies make the leap ... and others don't. New York, NY. HarperCollins Publishers.

5. Daudelin, M. W. (1996). Learning from experience through reflection. Organizational Dynamics, 24(3), 36-48.

6. $\quad$ Drucker, P. Managing oneself. (2005). Harvard Business Review, 83(1), 100-109.

7. Gabarro, J. J., \& Kotter, J. P. (1993). Managing your boss. Harvard Business Review, 71(3), 150-157.

8. Garvin, D. A. (2003). Learning in Action: A guide to putting the learning organization to work. Boston, MA.: Harvard Business School Publishing

9. Lencioni, P. (2002). The five dysfunctions of a team. San Francisco, CA: Jossey-Bass.

10. Robbins, S. R., \& Judge, T. A. (2011). Organizational behavior. $14^{\text {th }}$ edition. Upper Saddle River, NJ: Pearson/Prentice Hall.

11. Robinson, S. 1., \& Rousseau, D. M. (1994). Violating the psychological contract: Not the exception but the norm. Journal of Organizational Behavior, 15, 245-259.

12. Schlesinger, L (1996). It doesn't take a wizard to build a better boss. Fast Company, 3 (6), Retrieved from http://www.fastcompany.com/magazine/03/boss.html.

13. Shore, L. M., \& Barksdale, K. (1998). Examining a degree of balance and level of obligation in the employment relationship: a social exchange approach. Journal of Organizational Behavior, 19, 731-744.

14. Tannen, D. (1995). The power of talk: who gets heard and why. Harvard Business Review, 73(5), 138-148.

15. Simpson, L. (2002). Why managing up matters. Harvard Management Update, 7 (8), 3-5. 


\section{APPENDIX}

\section{Lessons Learned Emails}

From: Brad Kemper

Sent: Tuesday, March 10, 2009 9:27 AM

To: Jason Cochran

Cc: Brad Kemper

Subject: Bid Process - Lessons Learned

Jason,

The following is a list of a few things I've learned from the bid process:

- Take extra caution in proofreading bid forms, emails, etc. so that I don't have to send it out multiple times. This causes confusion.

- Give specific due dates for anything that I ask for from bidders.

- Have a deadline for subcontractors to inform NB that they are bidding so that we know who all will be bidding and can keep them updated throughout the process.

- When asking questions to bidders, have them explain to me how they envision the work being performed. Then, either correct them or consider their view. This way, I know what they understand and what they are still confused about.

- Make sure to pressure, or make it mandatory for subcontractors to attend the pre-bid meetings when the project is this complicated. Possibly have a second pre-bid meeting once they have had a chance to review the drawings and documents.

- Make sure they understand the importance of reviewing the documents and are not waiting until the last minute.

Thanks,

Brad Kemper

Project Engineer

NewBuild

Direct: (555) 555-2342

Fax: (555) 555-2700

Mobile: (555) 555-8271

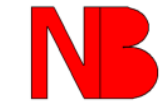


From: Kerry Smith

Sent: Tuesday, March 10, 2009 11:16 AM

To: Jason Cochran

Subject: Lessons Learned

Hello Jason,

Here are my lessons learned:

- Being more informed about the project.

- I started right into the process of calling bidders and revising documents but felt like I was not very informed about the project, meaning I felt like I didn't have time to look over drawings and specs.

- Next time, I need to become much more familiar with the project on my own, by looking over drawings and reading over the specs for my packages.

-Next time, I truly need to look at all drawing sets and not just the ones I thought were important to my packages because I missed information on the drawings set I didn't look at.

-Taking better \& detailed notes of the drawings and writing more QC's on items I see.

-Taking a little more time in revising the bid packages to meet the requirements of the project as well as making it more readable and easy to understand with my bidders (however some people will just never understand!!)

- doing a better job at keeping my initial bidders informed and even contacting Jason's and Brent's bidders to let them know that I am in charge of X, Y, Z packages.

-Doing a better and quicker job at scoping out my bidders

-Keeping organized at the beginning was difficult for me because I had just started and was trying to get into the work mode.

-Keeping better track of questions and answers, sent and received from bidders \& Jason through emails and phone conversations

-Working at my skills of writing RFI's

Kerry Smith

Project Engineer

NewBuild

Phone: (555) 555-4579

Fax: (555) 555-2700

kerry.smith@newbuild.com 


\title{
NOW WHAT DO I DO WITH BRAD AND KERRY?
}

\author{
Teaching Notes \\ Learning Objectives
}

After reading and studying this case, students should be able to:

1. Develop and describe the implications of the psychological contract that has developed between NewBuild and Brad and Kerry

2. Explain how and why Brad and Kerry should have learned how to manage Jason.

3. Use an approach to leadership that helps to identify Brad and Kerry's values, assumptions, beliefs, and expectations.

4. Apply a framework for understanding stylistic differences in information conveyed in written communication

5. Make a decision on whom to promote for the next big construction project.

\section{Discussion Questions}

1. What is the psychological contract developed between NewBuild and Brad and Kerry and how is it related to the decision Jason needs to make about Brad and Kerry's future?

2. Using Simpson's (2002) article or the one by Schlesinger (1996) on why managing up matters, what might Brad and Kerry have done to better manage Jason and their career at NewBuild?

3 In Clawson's (2001) article, "A Leader's Guide to why people behave the way they do," he stresses that to better motivate and lead, one needs to understand the values, assumptions, beliefs, and expectations, (VABEs) of various stakeholders in a given situation. Using this approach, identify the VABEs of Brad, Kerry and NewBuild

4. How might Tannen's (1995) article on linguistic style differences help Jason better understand the meaning and significance of the lessons learned emails for his decision on whom to promote?

5. Which employee should Jason promote to the next big construction project?

\section{Answers To Discussion Questions}

1. What is the psychological contract developed between NewBuild and Brad and Kerry and how is it related to the decision Jason needs to make about Brad and Kerry's future?

New employees like Brad and Kerry develop perceptions about an organization through its recruiting brochure, other company documents, and interactions with Jason and other employees. Over time, they also begin to get a feeling and understanding for the organizational culture. Through this process a psychological contract or understanding is developed which entails an implicit unwritten contract encompassing a reciprocal relationship. This contract involves a set of mutual expectations between Brad and Kerry and Jason, as a representative of the organization. In essence, Brad and Kerry agree to exert effort producing a certain amount of outputs in exchange for receiving certain inputs from the organization. (Robbins and Judge, 2011).

Since NewBuild has high expectations for all of its employees, in addition to a paycheck, Brad and Kerry might expect to receive in return respectful behavior in a non-bullying environment, challenging jobs, training to help them learn and grow on the job and perhaps a share in the organization's profits.

An example of a psychological contract in a high commitment-high performance organization like NewBuild is from Beer (2009). 
TN-1: Psychological Contract In High Commitment - High Performance Organization

\begin{tabular}{|c|c|}
\hline Management Expects & Employee Expects \\
\hline Dedication to mission and strategy & $\begin{array}{l}\text { Non-political culture in which management does the right } \\
\text { thing }\end{array}$ \\
\hline High performance & Groups work as teams to achieve organizational goals \\
\hline Behavior consistent with values & $\begin{array}{l}\text { Behavior is congruent with expressed and explicit values at all } \\
\text { levels of the organization, starting at the top }\end{array}$ \\
\hline Initiative & The what will be specified, not the how \\
\hline Collaboration and teamwork & $\begin{array}{l}\text { team performance is considered in organizational reward } \\
\text { system }\end{array}$ \\
\hline Self Management & $\begin{array}{l}\text { Input into decision making allowed once competence } \\
\text { demonstrated }\end{array}$ \\
\hline Flexibility & Freedom to use expert judgment in completing a task \\
\hline Unselfish contribution & Credit to be given where credit is due \\
\hline Openness to feedback and learning & Opportunity to convey unfiltered data to management \\
\hline Commitment to firm & $\begin{array}{l}\text { Employee development above and beyond any pay and } \\
\text { benefits } \\
\text { Good faith effort to avoid layoffs }\end{array}$ \\
\hline
\end{tabular}

Beer (2009)

It is in Jason's best interest to do the best he can to maintain a psychological contract involving mutually high expectations between Brad and Kerry and the organization since research has shown that actively supporting a psychological contract of high mutual expectations is related to: more support and commitment to the organization, more positive beliefs about their career, and less intention to leave the organization.

Unfortunately, psychological contracts are frequently broken. Research (Robinson and Rousseau, 1994) has shown that for employees reporting about their first job after college, more than half reported a violation of their psychological contract. In order to mitigate this effect, it is very important for the applicant and new employee to learn as much as possible about the job and fellow workers in order to develop a psychological contract based on reality. This can be accomplished by asking many questions at all stages of the recruitment and selection process. Realistic job previews developed by the organization that clearly convey both positives and negatives of the job are an excellent vehicle to help potential employees more accurately gauge the psychological contract of the organization.

Employee reaction to a disruption of the psychological contract can involve intense emotional reactions including: shock, moral outrage, indignation, resentment, and anger all accompanied by a strong sense of betrayal. Some observable manifestations of a dashed psychological contract include: reduced job satisfaction, lowered job performance, reduced commitment to the organization, reduced discretionary effort, and an increase in absenteeism, and cynicism towards the organization.

It would behoove Jason to play an active role in shaping an accurate high commitment psychological contract since this could increase an employee's trust and commitment to an organization while motivating the employee to fulfill her part of the exchange if she believes the organization is likely to do so (Shore and Barksdale, 1998).

In tough economic times like NewBuild is experienced, an employee could realistically expect a restructuring of the psychological contract. The economic climate fosters an environment of expectations focusing on business needs and not employee tenure. Perhaps in light of the changing times, NewBuild needed to revisit its side of the psychological contract especially with respect to career growth and development and long term employment. Jobs are becoming more demanding while offering less loyalty to employees. Through no fault of their own, employees are being required to play the role of free agent whose main concern is employability and reputation at the expense of loyalty to the organization. Unfortunately this restructuring tends to produce an environment in which employees are not fully engaged either mentally or physically but rather just seem to be physically present to do the job with little or no energy developed from intrinsic motivation. 
A quick review of the latest performance evaluations of Brad and Kerry indicated that their performance as assessed seemed identical, with ratings on all dimensions being at the midpoint of the 5 point scale. Perhaps the psychological contract now operational at NewBuild given the depressed economy has already served to attenuate the performance of the two newly hired engineers.

2. Using Simpson's (2002) article or the one by Schlesinger (1996) on why managing up matters, what might Brad and Kerry have done to have more actively managed Jason and their career at NewBuild?

It is crucial for employees like Brad and Kerry to actively manage their relationship with Jason in order to produce benefits for all concerned parties. They can begin to do this by focusing in on Jason's specific context, his strengths and weaknesses, pressure he feels from above and from his peers, and a combination of organizational and personal objectives he is trying to meet. This entails mentally shifting one's framework away from "I" to a broader world that includes "us." Gabarro and Kotter (1993), cited in Simpson (2002), remind us that developing effective work relationships with one's boss should not be viewed as political but rather as another important relationship to manage, like managing one's customers which are crucial for business success.

Some specific things that Brad and Kerry might have done were to clarify goals and expectations that Jason had for them and check regularly to determine if these changed over time. It is essential for Brad and Kerry to have determined Jason's personal objectives to ensure that they did not work against them. Another aspect of learning how to work more effectively with Jason was to assess his work style. Some areas which could be focused on include:

- Did he prefer a more organized and formal approach when meeting or was it acceptable to stop him in the hall at any time to convey important information?

- How best did Jason prefer to receive information (i.e., was he a listener or a reader)?

The overall goal here is to learn how to work best to accommodate your boss rather than bend your personality to fit his.

Another approach to analyzing how to best work with Jason can be found in Schlesinger (1996). Using characters from the Wizard of $\mathrm{Oz}$, he suggests how to best learn and grow from working for a boss best described as a scarecrow, a cowardly lion, or a tin man. For example if one is working for a scarecrow (a boss without brains) there exists an opportunity, if one is allowed considerable autonomy, to act like a leader. This entails analyzing a situation, determining what needs to be done, then taking action (Clawson, 2009) and asking for forgiveness after the fact rather than permission to act. Brad and Kerry might then be sure to attribute value-added contributions to the organization to Jason. A different scenario unfolds when one is working for a cowardly lion that refuses to take a stand. When encountering this particular situational dynamic, one's sense of passion for an issue is heightened thereby helping you determine where your passion lies and what is really important to you and worth battling over. Then it would be up to Brad and Kerry to activate their passion by marshalling all necessary resources including information, resources and support to provide a compelling business case for a proposed course of action.

A third type of boss Brad and Kerry need to learn to work with is the tin man, the cold, aloof boss seemingly without feeling or emotion with respect to relationship issues. In this situation, the boss' passion might lie with the business but not in being interpersonally competent. Brad and Kerry might have learned most and benefited from this type of boss-subordinate relationship by concentrating on the specific feedback and content of the feedback provided by the boss, rather than the process of delivery. Practice in dispassionately receiving strong, objective feedback can develop mental toughness in Brad and Kerry. It could also tangentially lead to the development of a support network cutting across the organization that does not include their boss. The essence of Schlesinger's work is to view the boss-subordinate relationship in a positive frame with the perspective that one need not be a passive recipient of organizational circumstances. If one chooses to be proactive rather than passive one might be able to learn from different types of bosses and thus be better able to actively manage their career.

Managing up also involves taking responsibility for a situation to best place you in a position to maximize your strengths. Drucker (2005) suggests that the best way to determine one's strengths is through effective feedback 
analysis. This might involve a detailed After Action Review (AAR) (Garvin, 2003) conducted regularly after significant organizational events in which you were a key player. By answering a series of questions like the following and reflecting on the answers, one is well placed in explicitly becoming aware of strengths and weaknesses. AAR questions might be:

- What were you trying to do?

- What happened?

- Why did it happen?

- What should be sustained?

- What should be changed?

- What was learned by working through this AAR?

At this point it seems that Kerry has done a better job of managing Jason than Brad, although it is unclear whether either of the two deliberately set about doing this on purpose. By effectively managing your boss one is seen as a team player who helps the boss get more accomplished.

3. In Clawson's (2001) article, "A Leader's Guide to why people behave the way they do," he stresses that to better motivate and lead, one needs to understand the values, assumptions, beliefs, and expectations, (VABEs) of various stakeholders in a given situation. Using this approach, identify the VABEs of Brad, Kerry and NewBuild

In order for managers to make informed developmental assignments for their subordinates, it is crucial to consider factors other than just previous observable behaviors. Effective managers need to be skillful at identifying and acting on the hidden values, assumptions, beliefs, and expectations (VABEs) of others (Clawson , 2001). VABEs are one's idiosyncratic internalization about the way the world is or should be. VABEs provide the mental building blocks upon which behavior is based.

Based on all we know in the case, these are a set of VABEs that appear to be operational:

Some potential VABEs for Brad might be:

- When asked to develop self insights about past experience, one should tend to focus on the role of others on performance.

- $\quad$ One should answer their boss truthfully when presented with a direct question but does nothing above and beyond to keep their boss informed on projects.

- $\quad$ One should believe that their boss will be told if anything extraordinary arises in the course of performing the task.

- $\quad$ Gentlemen should speak quietly and speak softly at work when one knows his boss is in direct earshot.

- One should actively seek and pursue new training opportunities when offered at work, especially if they are of the technical nature.

- In an unknown or unfamiliar situation, it is best to take a wait and see attitude.

- $\quad$ One should be succinct and demanding when dealing with others when one has the upper hand.

Some potential VABEs for Kerry might be:

- When asked to reflect on past performance, one can learn the most by focusing on one's own performance as a source of self insight and new learning.

- It is important to always keep the boss informed. This usually involves verbal as opposed to written communication on a regular basis.

- It is important to be heard and to express one's opinion at work; the best way to do this is in a polite, nonaggressive fashion.

- $\quad$ One does not have to over prepare for an event if one is quick thinking on their feet.

- $\quad$ One does not have to socialize with the team at work in order to be a good employee. 
- $\quad$ The best way to decide on what developmental opportunities to pursue if to first let peers test the waters to see what unfolds.

- It is important to have private time at work during lunch.

- Work-life balance is important. One should have a life that doesn't focus solely on work activities and people at work.

Some potential NewBuild VABEs might be:

- $\quad$ Strong and steady growth is the key to success.

- $\quad$ Be wise with your strategy and risk taking to ensure you will be able to weather any storm.

- It is important for the president of the company to serve as a role model with respect to fiscal responsibility in times of a downturn.

- $\quad$ It is important to promote from within and develop clear career paths for all employees.

- $\quad$ Planned developmental experiences are the lifeblood of the organization.

- It is important to take succession planning seriously.

- If an organization offers challenging job opportunities and treats employees fairly then turnover should be low or nonexistent for star employees.

- $\quad$ Hire competent people, give them lots of freedom and stay out of their way.

- $\quad$ Sometimes difficult decisions have to be made for the best of the organization as a whole

- How you take action is as important as what action you take.

Unless managers understand the core VABEs of people, they are not likely to be successful in guiding them through new and challenging developmental assignments. Once a manager learns something about the central VABEs of a coworker through listening, observing, and testing, the manager can assess whether these assumptions provide a basis for behavior that aligns with the objectives of the organization and its strategic intent. If the VABEs of a person do not match those of the organization's culture, it could demand of Jason an extended period of time coaching or mentoring or it could mean looking for a better alignment between the VABEs of that person in another organization.

In a specific situation in which Jason concluded that a subordinate's inappropriate behavior is based on assumptions that are fundamental to an individual's personality, the manager might be thinking of reassigning the individual to another job in a different part of the organization. Important VABEs that are central to one's core values are unlikely to change very easily. On the other hand, if the VABEs around a particular issue held by a subordinate seem to be on the periphery, then Jason might be successful if he attempts to surface the underlying assumptions and the behavioral consequences of these. He then might be in a better position to initiate a change in assumptions and thus a change in behavior.

A quick analysis based solely on the VABEs of Kerry, Brad and NewBuild suggests that promoting either one would seem reasonable, although the specific coaching needed to enable them to be successful might vary as a function of their different VABEs. It is clear that Jason is already frustrated about his progress on identifying and working with Brad. On the other hand, Kerry's VABEs tend to be consistent with other information available about her; this therefore makes Kerry a safer choice for promotion.

4. How might Tannen's (1995) article on linguistic style differences help Jason better understand the meaning and significance of the lessons learned emails for his decision on whom to promote?

Tannen (1995) writes that in US businesses, linguistic style differences tend to be especially noticeable between genders. The dominant style in practice tends to be male and because of stylistic differences, women might be unintentionally ignored, passed over for promotion, and interrupted even when they are highly competent. A few particular styles of communicating that may shed light on the incident include: asking questions, giving feedback, managing up, ritual fighting, accepting blame and admitting fault, taking credit, socializing, and expressing uncertainty and doubt, being indirect. 
One can see that Brad and Kerry's lessons learned emails in the Appendix are short and to the point however, several conversational style differences can be observed Jason has observed that Kerry freely elaborates on her projects when updating Jason and she sometimes shares information about her life outside work while Brad does not. Brad begins his email with "Jason" and Kerry adds a social greeting with "Hello Jason".

Kerry freely asks questions in the search for needed knowledge to effectively understand and complete her assigned tasks. Brad asks fewer questions and often remains silent even in those circumstances when he is confused or unclear about which direction to pursue in completing a task. Brad states, "When asking questions to bidders, have them explain to me how they envision the work being performed. Then, either correct them or consider their view. This way I know what they understand and what they are confused about." In this situation Brad is saying he asks questions not because he is confused but because others are confused and do not understand. He assigns blame to others and puts himself in a one-up position by correcting them.

Kerry readily accepts fault that she assigns to herself. For example, she notes that "I missed information on the drawings set I didn't look at" and "doing a better job at keeping my initial bidders informed" and "keeping organized at the beginning was hard for me because I had just started and was trying to get into the work mode" and "taking better and detailed notes". Each of these statements acknowledges a weakness or something that was done incorrectly.

Brad's statements are worded much differently and do not accept fault or admit being incorrect. For example, "Give specific due dates for anything I ask for from bidders" and "have a deadline for subcontractors to inform NewBuild that they are bidding" and, "Make sure they understand the importance of reviewing the documents and are not waiting until the last minute." Each of these statements focus on what he (Brad) can do so others do their job better. Lastly, Brad's lessons learned never acknowledge that he did anything incorrectly, only that he wants to improve.

In this situation, Jason needs to unequivocally convey to both Brad and Kerry that asking questions and sharing information are part of NewBuild's VABES, the goal being to surface and share information across boundaries.

Brad's language varied in different situations. In the lessons learned he used power language such as, "make sure to pressure, or make it mandatory for subcontractors to attend." However, in the negotiation simulation exercise, Brad seemed to avoid challenging others' ideas, and seemed reticent when stating his own ideas. Brad might have felt that by toning down his arguments in this negotiation interaction he was allowing his opponent to save face. According to Tannen (1995), the explanation that accounts for this apparent discrepancy is that he may have recognized that the other two people were superior and he placed himself in the hierarchy according to where he thought he belonged at this point and his subcontractors (roles in the negotiation) were subordinate to him. An unintended consequence of acting this way might be for Jason to assume that Brad lacks authority in this specific situation. Kerry on the other hand seemed to actively challenge her competitors but with a "velvet hand". In this particular situation, Jason might further question both Brad and Kerry in detail to determine itheir intent manifested in their negotiation behavior.

Another potential stylistic difference between Brad and Kerry might arise for Jason's consideration. Many workers are brought up to believe that it is not appropriate to highlight their achievements with their boss, due to the belief that the worker might appear to be boasting. An unfortunate unintended consequence might be that a manager might come to the conclusion in the absence of any other compelling data that little has been accomplished by the reticent employee. In analyzing the lessons learned emails from Brad and Kerry, clear stylistic differences can be observed. Brad's focus is on "looking out the window" towards those other than himself; his focus and attribution of behavior is external, largely looking to the outside to explain his experiences. Kerry on the other hand seems to be "holding up a mirror" where the crux of her learning is inner directed. (The reference to looking out the window versus looking $n$ the mirror was first articulated by Collins (2001) when describing the behavior of Level 5 leaders.) Kerry appears to be very introspective and evinces trust that Jason will not misinterpret her willingness to be open about herself as a sign of weakness. 
In the future when asking workers to develop lessons learned, Jason might ask his employees to reflect on the following trigger questions: what are the most important things you learned about: the task, your co-workers, and yourself? This approach to reflection was originally suggested by Daudelin (1996) including a fourth factor, learning about the external environment or the broader context in which the task is performed.

Based on this review of the emails, Kerry might seem to be a person that might be easier for Jason to work with and develop.

5. Given all of the information in the case, which employee should Jason promote and why?

Jason's job seems to be changing in the depressed economy, requiring him to spend an increasing amount of time pursuing, writing, and selling contract bids. This necessarily means less time available to develop and nurture new employees. Given this scenario, it seems reasonable to retain Kerry over Brad, since it appears Jason would need to spend less time coaching and working with her due to her ability to effectively reflect and to be introspective. Kerry seems to be somewhat more adaptable to changing circumstances and manages upward successfully keeping Jason informed. decision.

One might assemble the available information in the following table to better enable Jason to make his 
TN-2: Jason's Assessment of Brad and Kerry for Promotion

\begin{tabular}{|c|c|c|}
\hline & Brad & Kerry \\
\hline Psychological Contract & $\begin{array}{l}\text { This is the same for both Brad and Kerry. In the } \\
\text { past, NewBuild offered opportunities for growth } \\
\text { and challenge by putting new hires quickly into } \\
\text { major projects. In a way this compensated for a } \\
\text { lower salary. Company advertising might need } \\
\text { to be modified as opportunities for career growth } \\
\text { in recessionary economy is no longer } \\
\text { motivational. Both new employees might feel as } \\
\text { if they were hired under false pretenses in the } \\
\text { sense that the company no longer seems able to } \\
\text { deliver on past promises. } \\
\text { A revision on NewBuild's side of the contract } \\
\text { seems in order to reflect current economic } \\
\text { realities. } \\
\text { It is perhaps a reaction to Brad and Kerry's } \\
\text { perception of the employment contract that they } \\
\text { performed how they did (reiterated below) on the } \\
\text { performance evaluation. } \\
\text { They is no reason to expect that the } \\
\text { psychological contract between the new } \\
\text { employees and NewBuild would have exerted a } \\
\text { differential effect on their performance. }\end{array}$ & \\
\hline $\begin{array}{l}\text { Performance } \\
\text { Evaluation }\end{array}$ & $\begin{array}{l}\text { Scored } 3 \text { out of } 5 \text { on } 15 \text { dimensions of job } \\
\text { performance-"meets expectations" }\end{array}$ & $\begin{array}{l}\text { Scored } 3 \text { out of } 5 \text { on } 15 \text { dimensions of job } \\
\text { performance-"meets expectations" }\end{array}$ \\
\hline Managing Up & $\begin{array}{l}\text { Focus is only on Brad and answering questions } \\
\text { No big picture view of pressures, goals, etc } \\
\text { facing Jason. } \\
\text { Passive type approach to work situation might } \\
\text { make this difficult for Jason to learn how to } \\
\text { appreciate and execute }\end{array}$ & $\begin{array}{l}\text { Does a good job of keeping Jason informed. } \\
\text { Seems to intuitively know what Jason's needs to } \\
\text { know, perhaps unconsciously acting in a way to } \\
\text { facilitate a big picture perspective of situation. } \\
\text { Informal style of communicating with Jason } \\
\text { seems to realize that he is a listener and prefers } \\
\text { receiving information orally as opposed to being } \\
\text { a reader. }\end{array}$ \\
\hline $\begin{array}{l}\text { Performance on } \\
\text { Negotiation }\end{array}$ & $\begin{array}{l}\text { Did not assume leadership position expected; } \\
\text { passively went along with situation and with } \\
\text { whom he aligned. }\end{array}$ & $\begin{array}{l}\text { Impressive demonstration of thinking on her feet; } \\
\text { seemed to manifest some skills important to } \\
\text { dealing with contractors on major project. }\end{array}$ \\
\hline $\begin{array}{l}\text { Values, Assumptions, } \\
\text { Beliefs, Expectations } \\
\text { (VABEs) }\end{array}$ & $\begin{array}{l}\text { Tend to be somewhat self-centered and focused } \\
\text { on him. } \\
\text { Seemed to be marginally related to concern with } \\
\text { others or organization as whole }\end{array}$ & $\begin{array}{l}\text { Were centered on her and performance within a } \\
\text { larger context. } \\
\text { Indicates that she is capable of viewing the } \\
\text { situation from a broader perspective. }\end{array}$ \\
\hline $\begin{array}{l}\text { Email Lessons } \\
\text { Learned }\end{array}$ & $\begin{array}{l}\text { Attribution of poor performance tended to be } \\
\text { outer directed. } \\
\text { In "good to great" parlance seemed to be } \\
\text { attributing causes of poor or ineffective } \\
\text { performance to players by "looking outside of } \\
\text { window". }\end{array}$ & $\begin{array}{l}\text { Manifested a keen ability to reflect on own } \\
\text { behavior and develop insights on how to } \\
\text { personally improve in the future. } \\
\text { Tended to "look in the mirror" when discussing } \\
\text { performance that might need improvement }\end{array}$ \\
\hline Promotion Decision & $\begin{array}{l}\text { Brad might be promotable in the future if Jason } \\
\text { is able to devote sufficient time to coaching with } \\
\text { respect to managing up, appreciating the big } \\
\text { picture, and learning from experience through } \\
\text { reflection. Brad is not a poor performer but } \\
\text { perhaps is marginal given the constraints under } \\
\text { which Jason is operating at this point in time. } \\
\text { Kerry is the better person for the job on the next } \\
\text { big project. }\end{array}$ & $\begin{array}{l}\text { Kerry seems ready now to be promoted. She } \\
\text { seems more compatible with working with Jay's } \\
\text { approach to managing and leading. Seems to } \\
\text { have the ability to reflect and learn from her } \\
\text { mistakes. }\end{array}$ \\
\hline
\end{tabular}

